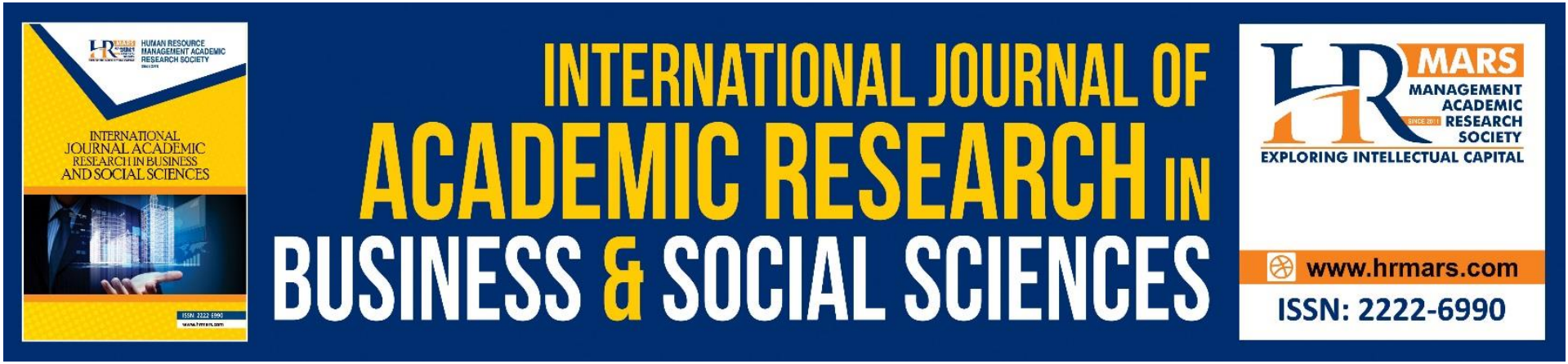

\title{
Operating Environment and Sustainability of Youth Empowerment Projects in Makueni County, Kenya.
}

\section{Ambrose Kyalo Kaumbulu, Stephen Makau Muathe, Rosemary James}

To Link this Article: http://dx.doi.org/10.6007/IJARBSS/v10-i12/8113

DOI:10.6007/IJARBSS/v10-i12/8113

Received: 02 November 2020, Revised: 29 November 2020, Accepted: 19 December 2020

Published Online: 31 December 2020

In-Text Citation: (Kaumbulu et al., 2020)

To Cite this Article: Kaumbulu, A. K., Muathe, S. M., \& James, R. (2020). Operating Environment and Sustainability of Youth Empowerment Projects in Makueni County, Kenya. International Journal of Academic Research in Business and Social ScienceS, 10(12), 264-276.

Copyright: @ 2020 The Author(s)

Published by Human Resource Management Academic Research Society (www.hrmars.com) This article is published under the Creative Commons Attribution (CC BY 4.0) license. Anyone may reproduce, distribute, translate and create derivative works of this article (for both commercial and non-commercial purposes), subject to full attribution to the original publication and authors. The full terms of this license may be seen at: http://creativecommons.org/licences/by/4.0/legalcode

Vol. 10, No. 12, 2020, Pg. 264- 276

Full Terms \& Conditions of access and use can be found at http://hrmars.com/index.php/pages/detail/publication-ethics 


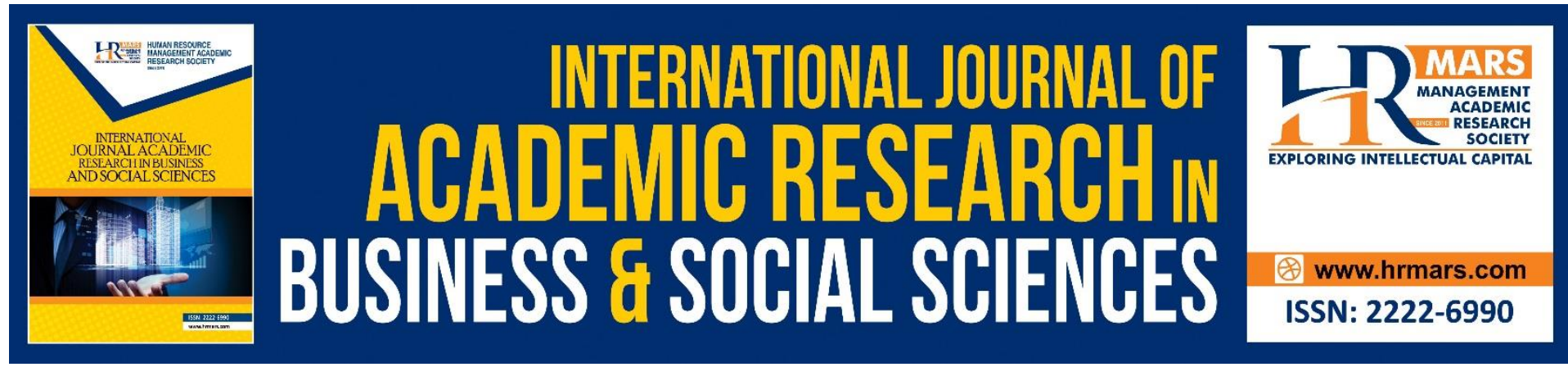

\title{
Operating Environment and Sustainability of Youth Empowerment Projects in Makueni County, Kenya.
}

\author{
Ambrose Kyalo Kaumbulu, Stephen Makau Muathe, Rosemary \\ James \\ School of Business Kenyatta University \\ Email:ambrosekyalo25@gmail.com,muathesm@yahoo.com,james.rosemary@ku.ac.ke
}

\begin{abstract}
Contextual factors may generate positive organizational-related results when aligned with internal organizational factors. This is an assertion that requires empirical justification in the Kenyan context through determining the effect of operating environment on sustainability of Youth Empowerment Projects. Hence this study examined the effect of the project operating environment on the sustainability of Youth Empowerment Projects in Makueni County, Kenya from a survey of 196 respondents. Descriptive and inferential analysis were carried out on data collected from 132 respondents, and the results of the analysis presented. The results showed that the effect of project operating environment on project sustainability was significantly. Therefore, according to the results of the analysis operating environment is an explanatory construct of project sustainability. The implication of the findings of this study is that the fit between contextual factors will contribute to sustainability of projects across Kenya.
\end{abstract}

Keywords: Resource-Based View, Contingency Theory, Project Governance, Operating Environment, Sustainability, Youth Empowerment, Kenya.

\section{Introduction}

An important critical success factor for project-related outcomes has been identified as the knowledge of the environment where project activities are undertaken. The environment is the context in which projects transpire and hence the successful project depends on the integration within the project environment of contextual factors (Zhu \& Mostafavi, 2017; Kaumbulu, Muathe \& James, 2020c). A multitude of literature have shown in project management literature that contextual variables can moderate the relationship between internal organizational factors and overall performance (Adeleke, Bahaudin, \& Kamaruddeen, 2016; Jabeen, 2014). In a low-income economy such as Kenya, however, studies examining the effect of contextual variables in the relationship between internal organizational factors and performance-related results largely remain anecdotal. A chunk of Youth Empowerment Projects have been implemented in Kenya, a sub-Saharan African region, fundamentally to ease youth unemployment and poverty in order to achieve Kenya's 2030 Vision (Honorati, 2015), and most of these projects had sustainability problems (Lenjo, 2018). Although 
research activities by academics in the Kenyan context concentrate on contextual variables as a backdrop to performance outcomes (Kayenria \& Karugu, 2020), there is also a need for empirical investigation as to whether the operating environment of the project is an explanatory variable predicting project sustainability.

\section{Review of Literature \\ Theoretical Literature Review \\ Contingency Theory}

Contingency Theory was postulated by Joan Woodward (1958) as a behavioural theory. The theory argued that there was no better way in managing. Admittedly, in certain cases, the efficient leadership style of an organization might work and fail in another; thus, effectiveness was based on different internal and external constraints (Fiedler, 1964). The Contingency Theory was linked to organizations (Burns \& Stalker, 1961) by advocates of this perception, highlighting that a project could not be systematically premeditated without its meaning. The project comparison to external contingencies was thus an influential factor in the temporary efficacy of the organisation. Contingency Theory was defined by Burns and Stalker (1961) as the difference between systemic and on-going organizations as they try to fit into static and dynamic environments. The idea of the Contingency Theory is that the environmental alignment of the project plays a crucial role in its outcomes (Hanisch \& Wald, 2012; Darwish et al., 2018).

Donaldson (1987) argued that the current definition of Contingency Theory mainly focuses on the adaptability of the organization to an environment that is continuously unpredictable. The context was, therefore, the decisive construct that initiated the variation. However, there is no hint of the context variable existence under which the mediating and moderating structures contribute to its results. The previous research investigated the degree to which an independent variable had an influence on the mediating variable, while the deceptive effect of the variable was reflected on a related dependent variable. The above tested the moderating variable to assess its intensity or existence in the relationship between an independent and a dependent variable. The intensity or existence of the interactional connection between operating environment and project sustainability in this research.

\section{Resource Based View (RBV) Theory}

The Resource-Based View Theory (RBV) is known as a modern-day approach that illustrates the way organizational resources and skills can produce competitive advantage (CA). It generated contributions in the fields of economics and strategic management from several scholars (Penrose, 1959; Porter, 1985; Wernerfelt, 1984; Barney, 1991). Consequently, Barney's contribution in 1991 formalized RBV as a current approach to recognizing the value of creating and sustaining internal organizational capital as a means of achieving sustainable competitive advantage.

Barney's (1991) perception of RBV is that across organizations, resources are heterogeneous and immobile; thus, a business that is able to build internal resources and capabilities that are deemed rare, valuable, inimitable and also non-substitutable may gain sustainable competitive advantage. Internal resources include, among others, properties, skills, information, expertise, company characteristics and organizational processes, and these are managed by an organization, enabling it to formulate and execute strategies that would increase its efficiency and effectiveness (Barney, 1991). 
RBV has also been criticized for its inability to define unique organizational tools that seldom have the characteristics of valuability, inimitability, and non-substitutability. RBV theory, however, has been an important theoretical prism for underpinning research among scholars in various disciplinary fields. Jugdev and Mathur (2013) argued that the RBV was a theoretical model for developing specific organizational project management capabilities, properties, facts, tacit knowledge, instruments and procedures. Therefore, because of its significant contribution to the development of sustainable projects, RBV becomes important as a resource, in terms of financing, manpower and services, which is necessary during the implementation of the project. Leveraging governance practices in different organisations will then contribute to capacity growth that would improve the sustainability of projects.

\section{Empirical Literature Review}

Sustainability of projects is an important problem facing humanity, taking into account the growth that meets present needs without undermining the ability of future generations to fulfill their individual needs (Brink \& Silvius, 2014). Project sustainability refers to the project's ability to achieve its primary goals after the initial sponsors of the project have withdrawn their support (Gonz'alez \& Perez, 2015). For Morfaw (2014), longevity of the project is the organizational capacity to continue the program and mission well into the future, as all projects would inevitably end, maintaining the project's positive impact. Sustainability of projects thus leads to improved project value, such as increased efficiency, improved quality of production, decreased living costs, profitability, and improved business (Carvalho \& Martens, 2016; Marcelino, Gonz'alez \& Perez, 2015). In particular, from project identification through feasibility studies, conception, design, assessment, financing, implementation, termination, monitoring and evaluation, definite standards and metrics should be developed for the sustainability of projects (Morfaw, 2014; Kaumbulu, Muathe \& James, 2020).

In project management, the increasing focus on sustainability is encouraging. The definition of sustainability, however, remains abstract, frequently difficult in operational and concrete terms to articulate (Silvius \& Schipper, 2014). To assess project sustainability, several management researchers have used various metrics. Ika (2012); Carvalho and Rabechini (2015) and Kaumbulu, Muathe and James, (2020a) argued that it was possible to quantify project sustainability for the required stakeholders in terms of social, economic and environmental benefits. In the same way, Carvalho and Senzi (2014) pointed out that sustainability interventions studied in project management and from different administration and engineering disciplines were based on three concepts: social aspect, economic aspect, and environmental aspect. Thomson et al (2011) considered sustainability concisely as an important tool for understanding the economic, environmental and social issues associated with the development, design, maintenance, operation and eventual removal of projects and their support structures.

Project sustainability has been evaluated in different ways utilizing holistic values, as shown in literature. Zhou et al (2013) concluded that the viability of the project can be operationalized in relation to the intended profit flow of users, the operational level of services, prove of actual project performance, project design and institutional support. In terms of project longevity, increased number of beneficiaries (youth), and decreased unemployment, Jassor (2016) and Lenjo and Moronge (2018) assessed project sustainability. Odenyo and James (2018) describe project sustainability measures: financial strength of the project, documented progress, capacity of the project to achieve its goals, enhancement of standards and recorded profitability. The choice of measures for sustainability relies on the 
priorities of the projects. Measuring project sustainability was denounced for the appropriation of programs to measure efficiency operating practices to boost sustainability, like economic operations. They concentrated, indeed, on institutional and strategic principles such as product growth (Martens \& Carvalho, 2016). Silvius and Schipper (2015) argued that the three Triple Bottom Line-TBL (Economic, Social and Environmental) metrics must be put into a system of causes, variables or constructs that can be used as a decision model by an entity seeking to enhance its sustainability.

There is intense discussion on the best sustainability indicator to assess project sustainability. Martens and Carvalho (2016) and Kaumbulu, Muathe and James, (2020b) postulated that in TBL: economic, environmental and social aspects, project sustainability should be calculated. This is because the viability of ventures is vital to their short-term and long-term survival. Similarly, youth empowerment project success would be better measured utilizing TBL metrics. This study assessed project sustainability for stakeholders in communities where youth development programs have been initiated in terms of social, environmental and economic benefits.

Today's project managers have to be accustomed to the economic, financial, political, cultural, organizational and social environmental risk factors of the project (Kaumbulu, Muathe \& James, 2020c). Comprehending this fact requires defining the context in which the project is operational and the influence of internal and external stakeholders on the successful outcome of the project. Therefore, the project management should be competent and informed of the external factors impacting the performance of the project in order to produce remarkable success due to the difficulty and high technicality of the operating environment. The project manager and their project team should therefore be responsive to the project environment, such as cultural, social and organizational environments, and relaxed with them (Kirsi, 2016).

The sustainability of the project is influenced by the different environmental factors that work both in the internal and external environments (Kaumbulu, Muathe \& James, 2020b). Forces from the internal setting may be regulated or subject to organizational exploitation. External environmental forces are essentially uncontrollable; they greatly affect the viability of the project. Political, economic, institutional, social and legal aspects are part of those external factors (Sang, 2015). Furthermore, for any project to be viable, these external factors are essential considerations (Jarkas \& Haupt, 2015). This is attributed to the uniqueness and dynamism of projects, the uncertainties, the many difficulties, the various strategies and methodologies and the various environments involved in project execution. Identifying and controlling possible external environmental variables therefore plays a critical role in optimizing project efficiency and achieving successful innovation for the company; they vary dramatically from project to project depending on several environments (Kaumbulu \& Sang, 2018).

In order to correctly assess the operating environment, an efficient project governance model is necessary, such as the economic, political, legal, and socio-cultural and complexity factors involved in project management and the project itself. Turner and Müller (2005) emphasized that the governing team of the project should ensure proper cooperation and communication between themselves. The mechanism of managing and mitigating external environmental factors will be improved through this cooperation and coordination, thereby delivering sustainable results for project stakeholders. Consequently, it is necessary for the attainment of sustainability to integrate government policies for realistic implementation of project policies, as these direct effective action. Hang et al. (2018) assume that project laws, 
regulations and operating environment policies are important in improving the model of project governance, thus suggesting that the operating environment of the project is important and significantly impacted on project governance.

Musa, Amirudin, Sofield and Aminu (2015) and Kaumbulu, Muathe and James (2020c) assessed the significant impact of the operating environment of projects on the relationship between project governance and project sustainability. They argue that the operating environment determines the manner in which the project is handled as the projects experience economic and political conditions that are difficult to monitor in the organization of the project. In addition, Sang (2015) argued that the sustainability of World Bank-funded projects was significantly influenced by project operating environment variables such as political, organizational and economic factors. Therefore, operating environmental variables, that is, political, economic and legal factors, may have a moderating impact on the organizational partnership between project governance and project sustainability (Kaumbulu, Muathe \& James, 2020a).

Operating environmental variables, such as the political element, have a major effect on the feasibility of projects. Ozorhon et al. (2007) opined that certain powers inside the external environment resulting from policies and performance that influence project sustainability are political influences. These variables include changes in laws and regulations, policy inconsistencies, violation of contract, limits of effect, and political violence (Sang, 2015). Political risks have been identified as a significant project sustainability setback after implementation, as stressed in the literature (WB, 2011). In financing the project and, ultimately, its sustainability, the political climate of a country is an important concern. In reality, political forces remain a key risk within the organizational climate that can disrupt projects at their critical point.

The threat to the economic climate impacts the feasibility of the project and, thus, its sustainability. Kaumbulu, Muathe and James (2020c) emphasizes that economic variables involved, among others, problems ranging from interest rates and unemployment. Consequently, there is a need to take into account economic forces in the external environment in order to ensure the feasibility and sustainability of a project. Efficient project management can lead to an improved operating environment, thereby enhancing the sustainability of projects. The relationship between project governance and project sustainability in the present study was moderated by project operating environment metrics that included political and legal considerations. The environment remains a key risk at its critical phase that can endanger projects.

The theoretical framework of contingency theory supports the argument that positive organizational results would be generated by the coordination of internal organizational variables and their contextual factors. In a similar way, RBV assumes that the internal resources and skills of the organization can be constructed and built to gain a competitive advantage. Drawing from these ideas, project governance is an internal organizational aspect and can contribute to project sustainability if properly matched with contextual factors. Thus, this research was guided by the following objective:

- To determine the effect of operating environment on sustainability of youth empowerment projects in Makueni County, Kennya

Moreover, this thesis hypothesized the following:

$H_{01}$ : Operating environment has no significant effect on the sustainability of Youth Empowerment Projects in Makueni County, Kenya 


\section{Research Methodology}

The research design was composed of both descriptive and explanatory research designs used in this analysis. Descriptive study design helps the researcher to consider the future behavior, attributes, and values and test theories of a population (Muathe, 2010, Cooper \& Schindler 2011). The goal is to define an exact description of events, individuals or circumstances. In addition, the investigator does not have any manipulative influence over the variables, thereby shielding them from bias. By testing the relationships and defining the causal relationship between variables, the explanatory study design tests the hypotheses (Saunders, 2009). In doing so, it seeks to figure out what is going on, analyzing phenomena; in addition to moderating and interfering relationships, it challenges the causal effect between the variables. Simple and cluster sampling techniques were used in data sampling. A sample size of 196 was obtained from a population of 400 comprising project managers, leaders, and representatives of Youth Empowerment projects in Makueni County, Kenya, using Krejcie and Morgan's (1970) formula. The study used a structured questionnaire as a data collection tool, and data collected from 132 respondents was analyzed descriptively and inferentially using the Statistical Package for Social Sciences analytical tools. The following equation were used to test the hypothesis:

First, model 3.1 which includes project operating environment as an explanatory variable was estimated as follows.

$$
P S=\beta_{0}++\beta_{1} P O E+\varepsilon_{i}
$$

Where: $P S=$ Project Sustainability

$\mathrm{POE}=$ Project Operating Environment

$\beta_{0}=$ constant term

$\varepsilon \mathrm{i}=$ regression residual

$\beta_{1}=$ regression coefficient

\section{Findings and Discussion}

\section{Profile Analysis of Respondents}

The profile analysis of the respondents was done and presented in percentages. The results of the analysis are presented in Table 1. 
Table 1 Demographic Profile of the Respondents

\begin{tabular}{|l|l|c|c|c|}
\hline & & \multicolumn{3}{|c|}{ Gender* Demographic Characteristics } \\
\hline & & Male & Female & Total \\
\hline Age & $20-29 y r s$ & 57 & 38 & 95 \\
\hline & $30-39 y r s$ & 25 & 9 & 34 \\
\hline & $40-49 y r s$ & 3 & 0 & 3 \\
\hline & Total & 85 & 47 & 132 \\
\hline Education & & & & 17 \\
\hline & Secondary & 11 & 6 & 12 \\
\hline & Diploma & 4 & 8 & 72 \\
\hline & Degree & 44 & 28 & 28 \\
\hline & Masters & 23 & 5 & 3 \\
\hline & PhD & 3 & 0 & 132 \\
\hline & Total & 85 & 47 & 108 \\
\hline Duration & & & & 24 \\
\hline & 1-5years & 63 & 45 & 132 \\
\hline & $6-10 y e a r s$ & 22 & 2 & 23 \\
\hline & Total & 85 & 47 & 15 \\
\hline Position & & & & 132 \\
\hline & Project leader & 19 & 4 & 0 \\
\hline & Project official & 15 & 43 & \\
\hline & Member & 51 & 47 & \\
\hline & Total & 85 & & \\
\hline
\end{tabular}

As shown in Table 1, the profile distribution of respondents indicates that $72 \%$ were between 20 and 29 years of age and $25.7 \%$ were between 30 and 39 years of age, representing more male than female, across the age brackets. On the other hand, only 2.3 percent of the participants were 40 to 49 years of age. Most of the respondents ( 54.5 percent had university degree, another 21 percent had master's degree and 2.3 percent doctoral qualifications) in terms of the distribution by level of education. 9.1 percent were those with diploma academic qualification, while 12.9 percent had secondary education. The project period distribution revealed that the majority of respondents ( 81.8 percent) participated in the project for 1 to 5 years, while 18.2 percent spent 6 to 10 years working on the youth empowerment project. The effect of the findings is that most of the participants in this study participated in the project long enough to obtain appropriate work experience. The distribution of positions held showed that the majority of respondents (71.2\%) were team participants, followed by $17.4 \%$ who were project leaders. 11.4 percent of the sample was represented by project officials. This infers representativeness of all units of the project in the sample.

\section{Descriptive Statistics}

Descriptive statistics of variables was interpreted using parameters such as sample mean and standard deviation. The descriptive statistics results are shown in Table 1. 
Table 2 Descriptive Statistics of Variables

\begin{tabular}{|c|c|c|}
\hline \multirow{2}{*}{ Variable } & \multicolumn{2}{|c|}{ Aggregate Score } \\
\cline { 2 - 3 } & Mean & Standard Deviation \\
\hline Project Operating Environment & 4.24 & 0.64 \\
\hline Project Sustainability & 4.26 & 0.62 \\
\hline
\end{tabular}

As shown in Table 2, the cumulative mean score for the operating environment of the project stood at 4.24 and the standard deviation score was 0.64. Based on the scale adopted in this analysis, these scores show that the respondent agreed to the items measuring the operating environment of the project, while at the same time reducing the variability of responses among respondents. The sustainability framework had an aggregate mean score of 4.26 and a standard deviation score of 0.62 . These scores indicate agreement based on the scale adopted in this research, as well as low response variability. The overall analysis of the scores shows that the respondents were aware of the different methods for operating environment relating to project sustainability in their environment. The results of the descriptive statistics were consistent with previous studies' findings (Musa et al (2015).

\section{Test of Hypotheses}

Test of Hypothesis Two: Project operating environment has no significant effect on the sustainability of Youth Empowerment Projects in Makueni County, Kenya

The study also sought to find the significant effect of operating environment on the sustainability of projects in Makueni County, Kenya. To determine the hypothesis of significant moderating effect, hierarchical regression statistics was employed and the results of the statistics were interpreted following the decision criteria proposed by Baron and Kenny (1989). The results of the hierarchical regression statistics are as indicated in Table 4.

Table 3 Regression Results for Hypothesis of direct effect

\begin{tabular}{|l|c|c|c|c|c|c|}
\hline & $\mathrm{R}^{2}$ & $\mathrm{Adj}^{2}$ & $\mathrm{~F}$-val. & $\mathrm{B}$ & $\mathrm{T}$ & $\begin{array}{c}\text { Sig. } \\
0.05\end{array}$ \\
\hline Model & 0.732 & 0.728 & 176.194 & & & 0.000 \\
\hline $\begin{array}{l}\text { Operating. } \\
\text { Environment }\end{array}$ & & & & 0.353 & 5.516 & 0.000 \\
\hline Sustainability & - & - & - & 1.967 & 8.997 & 0.000 \\
\hline
\end{tabular}

As presented in Table 4, both the independent variable (Operating Environment) were introduced to the first model in the first stage of the analysis, and the results of the regression indicated that the operating environment was Operating Environment: $\beta=0.353, \mathrm{t} 5.516, p$ $5.516, p 5.516)$. Such findings have shown that the operating environment can also act as an explanatory variable. The hypothesis of no significant effect was not realized, therefore, not accepted. Therefore, the operating environment significantly affected the sustainability of Youth Empowerment Projects in Kenya. The results of significant effects of contextual factors were also in line with previous research findings that the relationship between organizational internal factors and project sustainability was predicted by the project environment (Amjad, 2018). 


\section{Conclusion and Policy Recommendation Conclusion}

The study sought to find whether operating environment significantly predicts the sustainability of Youth Empowerment projects in Kenya. The study formulated hypothesis to achieve this objective and the tested hypothesis showed that operating environment had a significant effect on sustainability. From the findings, project operating environment predicted sustainability of youth empowerment projects, thus implying that, with a stable project operating environment yielding superior sustainability results.

\section{Theoretical and Contextual Implications}

The strength of this study lies in the findings of the significant moderating effect of project operating environment in the relationship between project governance and sustainability of projects. These findings contribute to the body of knowledge in project management literature that when contextual factors are considered in the implementation of governance practices, then positive organisational outcomes will be generated. This evidence of significant moderating effect project operating environment is significant contribution to the body of literature, especially in a Kenyan context where empirical justification moderating effect of project operating environment is lacking. In addition, the theoretical reasoning from contingency theory is also supported by the findings of full moderating effect of project operating environment.

\section{Policy Implications}

The findings of this study would be useful for the various stakeholders in the policies relating to the management and execution of project activities that do not take place outside their environment; contextual variables must be given significant consideration in order to achieve project-related performance. In addition, project management should provide a secure operating environment for the project by mitigating the impact of chance on organizational management during the project, defining relevant guidelines, regulations and policies to be adhered to, mitigating disputes between stakeholders, increasing everyone's engagement in policy implementation, and encouraging project users' cooperation.

\section{Limitation Future Research Implications}

The study tested the direct effect of the project operating environment on sustainability of youth empowerment projects in Makueni County. Future research may consider the use of operating environment as a moderator to test its total effect on sustainability youth empowerment projects. This study is carried out in the Kenyan context, so it is not possible to generalize the results of the direct impact of the project operating environment to other sub-Saharan African countries as environmental factors vary from country to country. In order to better generalize the results, future researchers should also discuss studies on the construct of the project operating environment in other sub-Saharan Africa countries. The coefficient of determination in this study was $74.5 \%$, and this therefore indicates that there are other variables not examined in this study that can contribute to the explanation of sustainability of projects. 


\section{References}

Adeleke, A. Q., Bahaudin, A. Y., \& Kamaruddeen, A. M. (2016). Rules and regulations as potential moderator on the relationship between organizational internal and external factors with effective construction risk management in Nigerian construction companies: a proposed framework. In AIP Conference Proceedings, 1761(1) 020008.

Aubry, M., Richer, M-C., \& Lavoie-Tremblay, M. (2014). 'Governance performance in complex environment: The case of a major transformation in a university hospital', International Journal of Project Management, vol. 32, no. 8, 1333-1345.

Barney, J. (1991). Firm resources and sustained competitive advantage. Journal of management, 17(1), 99-120.

Beleiu, I., \& Nistor, R. (2015). Project governance and its contribution to projects success. Managerial Challenges of the Contemporary Society, 8 (1), 82-86.

Biesenthal, C., \& Wilden, R. (2014). Multi-level project governance: Trends and opportunities. International Journal of Project Management, 32(8), 1291-1308.

Burns, T., \& Stalker, G. M. (1961). The management of innovation. London. Tavistock Publishing, 62, 42-54.

Cooper, D. R., \& Schindler, P. S. (2011). Qualitative research. Business research methods, 4(1), 160-182.

Darwish, S., Abdo, H., \& AlShuwaiee, W. M. (2018). Opportunities, challenges and risks of transition into renewable energy: the case of the Arab Gulf Cooperation Council. International Energy Journal, 18(4).

De Brucker, K., Macharis, C., \& Verbeke, A. (2013). Multi-criteria analysis and the resolution of sustainable development dilemmas: A stakeholder management approach. European journal of operational research, 224(1), 122-131.

Dulaimi, M., \& Hariz, A. (2011). The impact of cultural diversity on the effectiveness of construction project teams. Engineering Project Organization Journal, 1(4), 213-221.

Fielder, F. E. (1964). A contingency model of leadership performance.

Hanisch, B. \& Wald, A. (2012). A bibliometric view on the use of contingency theory in project management research. Project Management Journal, 43(3), 4-23.

Haq, S. U., Liang, C., Dongxiao, G., \& Yinchao, M. (2016). “Understanding the Determinants of Project Performance: Empirical Evidences from Software Houses of Pakistan",WHICEB2 016 Proceedings. 8. Retrieved from http://aisel.aisnet.org/whiceb2016/8.

Honorati, M. (2015). The impact of private sector internship and training on urban youth in Kenya. The World Bank.

Ika, L. A. (2012). Project management for development in Africa: Why projects are failing and what can be done about it. Project management journal, 43(4), 27-41.

Jabeen, R. (2014). Moderating effect of external environment on performance of SMEs in Pakistan (Doctoral dissertation, Universiti Utara Malaysia).

Jassor, M. (2016). Factors Influencing Sustainability of Youth Group Projects Funded By Youth Enterprise Development Fund in Bomet County, Kenya, 99.

Jugdev, K., \& Mathur, G. (2013). Bridging situated learning theory to the resource-based view of project management. International Journal of Managing Projects in Business.

Kaumbulu, A. K., Muathe, S. M., \& James, R. (2020a). Sustainability of Youth Empowerment Projects: The Role of Project Governance in Makueni County, Kenya. Journal of Economics and Sustainable Development, 11 (20), 122-136. 
Kaumbulu, A. K., Muathe, S. M., \& James, R. (2020b). Governance Issues, Quality and Sustainability: Fact or Fallacy in Youth Empowerment Projects in Kenya. International Journal of Economics, Commerce and Management, 8 (10), 426-437.

Kaumbulu, A. K., Muathe, S. M., \& James, R. (2020c). Governance Strategy and Sustainability: The Role of Project Operating Environment of Youth Empowerment Projects in Kenya. International Journal of Research, 7, (9), 116-131.

Kaumbulu, A. K., \& Sang, P. (2018). Assessment of Critical Risks and Influence on the Success of Construction Projects. Scholars Bulletin (Management). DOI: 10.21276/sb.2018.4.3.3

Kanyeria, R. N., \& Karugu, J. (2020). Influence of External Business Environment on the Success of Health Projects in Nyandarua County, Kenya. International Journal of Business Management, Entrepreneurship and Innovation, 2(1), 1-16.

Kirsi, K. M. (2016). Analyzing operational environment: Financial sustainability of Tanzania civil society.

Krejcie, R. V., \& Morgan, D. W. (1970). Determining sample size for research activities. Educational and psychological measurement, 30(3), 607-610.

Lechler, T., \& Dvir, D. (2010). An alternative taxonomy of project management structures: linking project management structures and project success. IEEE Transactions on Engineering Management, vol. 57, no. 2, 198-210.

Lenjo, M. M. (2018). Drivers of Sustainability of Youth Empowerment Projects in Taita Taveta County, Kenya. Strategic Journal of Business \& Change Management, 5(2).

M'aburi, J. K. (2017). Effect of Project Governance on Performance of Constituency Development Funded Projects in Kajiado County. Strategic Journal of Business \& Change Management, 4(4).

Marcelino-Sádaba, S., González-Jaen, L. F., \& Pérez-Ezcurdia, A. (2015). Using project management as a way to sustainability. From a comprehensive review to a framework definition. Journal of cleaner production, 99, 1-16.

Martens, M. L., \& Carvalho, M. M. (2017). Key Factors of Sustainability in Project Management Context: A Survey Exploring the Project Managers' Perspective. International Journal of Project Management, 35(6), 1084-1102.

Morfaw, J. (2014). Fundamentals of project sustainability. Project Management Institute.

Muathe, S. M. A. (2010). The Determinants of Adoption of Information and Communication Technology by Small and Medium Enterprises within the Health Sector in Nairobi, Kenya. Unpublished PhD Thesis, Kenyatta University

Müller, R. (2009). Project Governance (Fundamentals of project management). Ashgate Publishing Group.

Müller, R., \& Lecoeuvre, L. (2014). Operationalizing governance categories of projects. International Journal of Project Management, 32(8), 1346-1357.

Musa, M. M., Bin Amirudin, R., Sofield, T., \& Musa, M. A. (2015). Influence of external environmental factors on the success of public housing projects in developing countries. Construction Economics and Building, 15(4), 30.

Obare, J. O. (2017). Project Team Diversity, Implementation Process of Project Control Systems and Performance of Rural Roads Construction Projects in Kenya (PhD Thesis, University of Nairobi).

Ochunga, F. O. \& Awiti, L. H. (2017). Influence of Stakeholder Participation on Sustainability of Community Development Projects Implemented by Plan International in Homa Bay 
Town Sub-County, Kenya. International Journal of Academic Research in Business and Social Sciences, 7(4), 375-400.

Odenyo, C., \& James, R. (2018). Influence of Resource Mobilization on Sustainability of Women Group Projects in Vihiga County, Kenya. International Journal of Economics, Business and Management Research. 2(4), 2456- 7760

Penrose, E. T. (1959). The Theory of the Growth of the Firm. New York: John Wiley.

Porter, M. E., \& Kramer, M. R. (2011). The Big Idea: Creating Shared Value. How to reinvent capitalism-and unleash a wave of innovation and growth. Harvard Business Review, 89(1-2).

Sang, P. K. (2015). Sustainability of World Bank Funded Projects in Kenya. Kenya: (PhD Thesis Kenyatta University).

Saunders, M., Lewis, P., \& Thornhill, A. (2009). Research methods for business students. Pearson education.

Silvius, A. G., \& Schipper, R. (2012). Sustainability in Project Management Competences in Conference proceedings. Elsevier.

Too, E. G., \& Weaver, P. (2014).The Management of Project Management: A Conceptual Framework for Project Governance. International Journal of Project Management, Vol. 32(8), 1382-1394.

Wernerfelt, B. (1984). A Resource-Based View of the Firm, Strategic Management Journal,5(2), 171-180.

Wu, G., Zhao, X., Zuo, J., \& Zillante, G. (2019). Effects of team diversity on project Performance in Construction Projects. Engineering, Construction and Architectural Management, 26(3), 408-423.

Zhu, J., \& Mostafavi, A. (2017). Characterization of the underlying mechanisms of vulnerability in complex projects using dynamic network simulation. In 2017 Winter Simulation Conference (WSC) (PP. 2436-2447). IEEE.

Zwikael, O., \& Smyrk, J. (2015). Project governance: Balancing control and trust in dealing with risk', International Journal of Project Management, vol. 33(4), 852-62. ww.ctan.org/tex-archive/help/Catalogue/entries/graphicx.html. 